NASA/TM-2000-209653

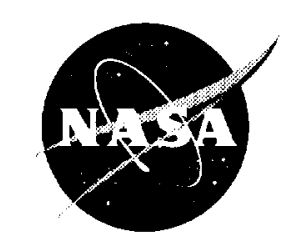

\title{
SiC-Based Gas Sensor Development
}

G.W. Hunter, P.G. Neudeck, and M. Gray

Glenn Research Center, Cleveland, Ohio

D. Androjna

Cortez III Service Corporation, Cleveland, Ohio

L-Y. Chen

AYT Corporation, Brook Park, Ohio

R.W. Hoffman, Jr.

Ohio Aerospace Institute, Brook Park, Ohio

C.C. Liu and Q.H. Wu

Case Western Reserve University, Cleveland, Ohio 
Since its founding, NASA has been dedicated to the advancement of aeronautics and space science. The NASA Scientific and Technical Information (STI) Program Office plays a key part in helping NASA maintain this important role.

The NASA STI Program Office is operated by Langley Research Center, the Lead Center for NASA's scientific and technical information. The NASA STI Program Office provides access to the NASA STI Database, the largest collection of aeronautical and space science STI in the world. The Program Office is also NASA's institutional mechanism for disseminating the results of its research and development activities. These results are published by NASA in the NASA STI Report Series, which includes the following report types:

- TECHNICAL PUBLICATION. Reports of completed research or a major significant phase of research that present the results of NASA programs and include extensive data or theoretical analysis. Includes compilations of significant scientific and technical data and information deemed to be of continuing reference value. NASA's counterpart of peerreviewed formal professional papers but has less stringent limitations on manuscript length and extent of graphic presentations.

- TECHNICAL MEMORANDUM. Scientific and technical findings that are preliminary or of specialized interest, e.g., quick release reports, working papers, and bibliographies that contain minimal annotation. Does not contain extensive analysis.

- CONTRACTOR REPORT. Scientific and technical findings by NASA-sponsored contractors and grantees.
- CONFERENCE PUBLICATION. Collected papers from scientific and technical conferences, symposia, seminars, or other meetings sponsored or cosponsored by NASA.

- SPECIAL PUBLICATION. Scientific, technical, or historical information from NASA programs, projects, and missions, often concerned with subjects having substantial public interest.

- TECHNICAL TRANSLATION. Englishlanguage translations of foreign scientific and technical material pertinent to NASA's mission.

Specialized services that complement the STI Program Office's diverse offerings include creating custom thesauri, building customized data bases, organizing and publishing research results ... even providing videos.

For more information about the NASA STI Program Office, see the following:

- Access the NASA STI Program Home Page at http://www.sti.nasa.gov

- E-mail your question via the Internet to help@sti.nasa.gov

- Fax your question to the NASA Access Help Desk at (301) 621-0134

- Telephone the NASA Access Help Desk at (301) 621-0390

- Write to:

NASA Access Help Desk

NASA Center for AeroSpace Information 7121 Standard Drive

Hanover, MD 21076 
NASA/TM-2000-209653

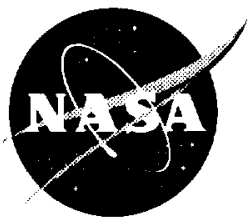

\section{SiC-Based Gas Sensor Development}

G.W. Hunter, P.G. Neudeck, and M. Gray

Glenn Research Center, Cleveland, Ohio

D. Androjna

Cortez III Service Corporation, Cleveland, Ohio

L-Y. Chen

AYT Corporation, Brook Park, Ohio

R.W. Hoffman, Jr.

Ohio Aerospace Institute, Brook Park, Ohio

C.C. Liu and Q.H. Wu

Case Western Reserve University, Cleveland, Ohio

Prepared for the

1999 International Conference on Silicon Carbide and Related Materials sponsored by North Carolina State University

Raleigh, North Carolina, October 10-15, 1999

National Aeronautics and

Space Administration

Glenn Research Center 


\section{Acknowledgments}

The authors would like to acknowledge the contributions of Dr. J.F. Lei, Dr. G. Fralick, Dr. R. Okojie, F. DeAngelo, and Dr. D. Larkin of NASA Glenn and C. Salupo of Cortez III/NASA Glenn. Send correspondences

to G. Hunter, E-mail: ghunter@grc.nasa.gov

Available from

NASA Center for Aerospace Information

7121 Standard Drive

Hanover, MD 21076

Price Code: A03
National Technical Information Service 5285 Port Royal Road Springfield, VA 22100 Price Code: A03 


\title{
SiC-BASED GAS SENSOR DEVELOPMENT
}

\author{
G.W. Hunter, P.G. Neudeck, M. Gray \\ National Aeronautics and Space Administration \\ Glenn Research Center \\ Cleveland, Ohio 44135 \\ D. Androjna \\ Cortez III Service Corporation \\ Cleveland, Ohio \\ L-Y. Chen \\ AYT Corporation \\ Brook Park, Ohio 44142 \\ R.W. Hoffman, Jr. \\ Ohio Aerospace Institute \\ Brook Park, Ohio 44142 \\ C.C. Liu and Q.H. Wu \\ Case Western Reserve University \\ Cleveland, Ohio 44106
}

\begin{abstract}
Silicon carbide based Schottky diode gas sensors are being developed for applications such as emission measurements and leak detection. The effects of the geometry of the tin oxide film in a $\mathrm{Pd} / \mathrm{SnO}_{2} / \mathrm{SiC}$ structure will be discussed as well as improvements in packaging SiC-based sensors. It is concluded that there is considerable versatility in the formation of SiC-based Schottky diode gas sensing structures which will potentially allow the fabrication of a SiC-based gas sensor array for a variety of gases and temperatures.
\end{abstract}

\subsection{Introduction}

Silicon carbide-based gas sensors are of considerable interest since they can be operated at high temperatures and detect gases, such as hydrocarbons $\left(\mathrm{C}_{\mathrm{x}} \mathrm{H}_{\mathrm{y}}\right)$ and nitrogen oxides $\left(\mathrm{NO}_{\mathrm{x}}\right)$, which are important in various applications such as emission monitoring and leak detection. Our development of SiC-based gas sensors has centered on investigations of gas sensitive Schottky diodes. The major advantage of a Schottky diode in gas sensing applications is its high sensitivity. While a simple palladium $(\mathrm{Pd})$ on $\mathrm{SiC}(\mathrm{Pd} / \mathrm{SiC})$ Schottky diode structure has the advantage of high sensitivity, these sensors drift with extended heating at high $\left(400^{\circ} \mathrm{C}\right)$ temperature [1]. Efforts are underway to stabilize the Schottky sensor structure for long-term, high temperature operation [2].

One approach incorporates chemically reactive materials such as metal oxides into a SiC-based metal-insulator-semiconductor (MIS) Schottky diode structure. Unlike Si-based electronics, SiCbased devices can be operated at high enough temperatures for these materials, e.g. tin oxide $\left(\mathrm{SnO}_{2}\right)$, to be reactive to $\mathrm{C}_{\mathrm{x}} \mathrm{H}_{\mathrm{y}}$ and $\mathrm{NO}_{\mathrm{x}}$. This results in a metal-reactive insulator-semiconductor (MRIS) 
gas sensor structure. Potential advantages of this structure include increased sensor sensitivity and stability. Varying the reactive insulator composition can vary sensor selectivity to various gas species. We previously demonstrated this structure with $\mathrm{SnO}_{2}$ as the reactive insulator and compared the reactive insulator sensor response to that of a $\mathrm{Pd} / \mathrm{SiC}$ structure on the same chip (Figure 1a) [2]. The MRIS sensor showed improved stability and different responses than the $\mathrm{Pd} / \mathrm{SiC}$ sensor.

This approach, combined with metal-alloys directly on SiC [2], potentially yields wide flexibility in the design and operational capabilities of SiC-based gas sensing Schottky diodes. Various reactive oxides and metal alloys can be combined within the Schottky diode structure to tailor the diode response to specific applications. Work is on-going to develop a high temperature electronic nose consisting of an array of appropriately tailored gas sensors based on $\mathrm{SiC}$ and other materials [3]. However, this work depends on the ability to package these sensors for the appropriate operating conditions. This paper discusses our on-going development of SiC-based gas sensors. First, the effect of the geometry of the insulator on the MRIS sensor behavior was studied. Second, a prototype sensor package allowing high temperature operation of the sensor in ambient conditions will be discussed.

\subsection{Device Fabrication and Testing}

The SiC-based sensors are fabricated from chips with a 4-5 $\mu \mathrm{m}$ thick alpha-SiC epilayer grown by chemical vapor deposition on a commercially available off-axis alpha-SiC substrate. A backside contact is achieved by sputtering aluminum onto the bottom of the wafer. The MRIS sensor investigated in this work is shown schematically in Figure 1b. A thin layer of approximately 50 angstroms $(\AA)$ of $\mathrm{SnO}_{2}$ is sputter deposited onto half of the as-grown $\mathrm{SiC}$ epilayer surface (layer $\mathrm{SnO}_{2}$ configuration). On both halves of the wafer, open circular patterns of $200 \mu \mathrm{m}$ diameter were formed using photoresist. The $\mathrm{SnO}_{2}$ layer half (left half of Figure $1 \mathrm{~b}$ ) of the wafer was then covered masking off the circular photoresist patterns; on the other half of the wafer $50 \AA \mathrm{SnO}_{2}$ contacts (diode $\mathrm{SnO}_{2}$ configuration) were formed by sputter deposition using the same parameters as the first $\mathrm{SnO}_{2}$ deposition. The layer side was then uncovered and circular palladium (Pd) contacts approximately 400 angstroms ( $\AA$ ) thick were formed on both sides by sputter deposition and the subsequent lift-off. Thus, the $\mathrm{SnO}_{2}$ is deposited completely across the surface (layered configuration on the left half of Figure lb) on roughly half the chip while on the other half $\mathrm{SnO}_{2}$ is deposited only beneath the Pd contact (diode configuration surface on the right half of Figure $1 \mathrm{~b}$ ). The difference between the two sides of the chip is the geometry of the $\mathrm{SnO}_{2}$ layer beneath the Pd. This is in contrast to the previous tests (Figure 1a) where half the chip had the $\mathrm{SnO}_{2}$ layer beneath the $\mathrm{Pd}$ and the other half had no $\mathrm{SnO}_{2}$ at all beneath the $\mathrm{Pd}$. 

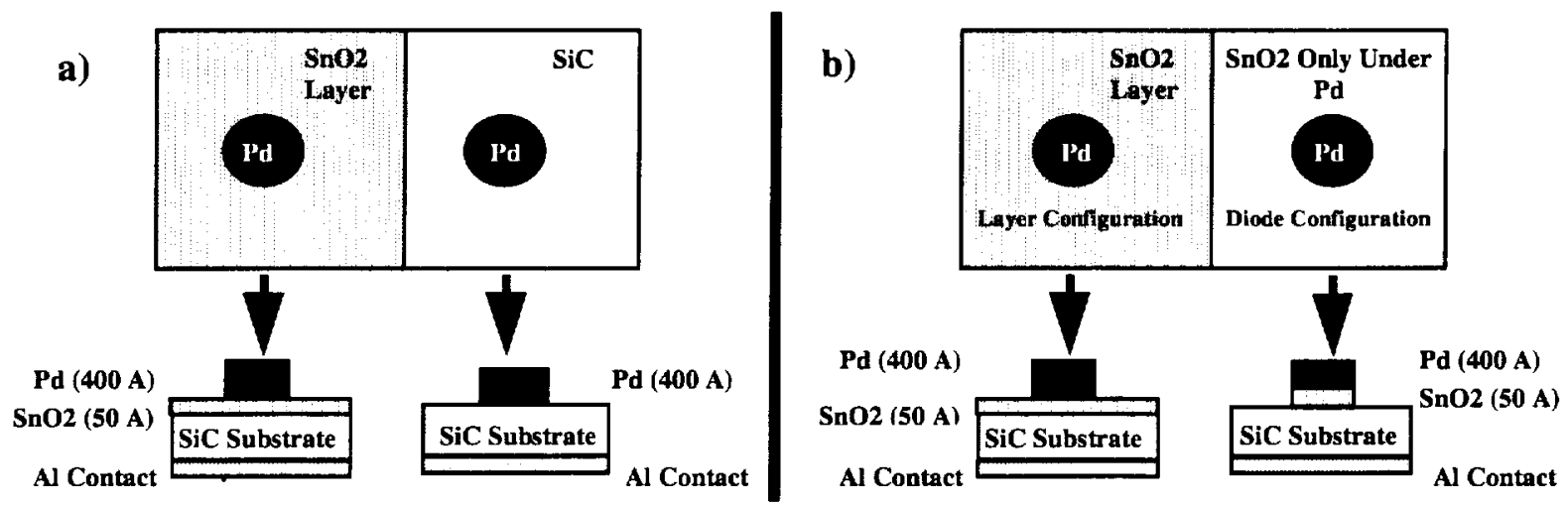

Figure 1: A schematic drawing of the test structures for: a) the MRIS approach which compared a Pd/SiC diode to a $\mathrm{Pd} / \mathrm{SnO}_{2} / \mathrm{SiC}$ diode. (Ref. 2) b) the effect of the reactive insulator $\left(\mathrm{SnO}_{2}\right)$ geometry on the sensor behavior of a $\mathrm{Pd} / \mathrm{SnO}_{2} / \mathrm{SiC}$ diode.

The gas sensor testing facility and sample connections have been described elsewhere [1]. The sample rested on a hot stage whose temperature is controlled from room temperature to $425^{\circ} \mathrm{C}$. Current-time (I-t) measurements were taken to characterize the diode response as a function of time during exposure to a variety of gases, and current-voltage (I-V) measurements were taken to characterize the diode's electronic properties in a given environment. The forward voltage at which the current is measured is chosen to maximize diode response and minimize series resistance effects.

\subsection{Results and Discussion}

\subsection{Effects of Reactive Insulator Geometry}

Heating the structures in Figure $1 \mathrm{~b}$ at $350^{\circ} \mathrm{C}$ for extended periods has shown a difference in behavior between the layer configuration sensors and diode configuration sensors (Figure 2). Both sensors are first exposed to air (10 minutes), nitrogen plus $10 \%$ oxygen (15 minutes), nitrogen plus $10 \%$ oxygen and $2500 \mathrm{ppm}$ hydrogen, denoted as $\mathrm{H}_{2} \mathrm{mix}$, ( 15 minutes), followed by nitrogen plus $10 \%$ oxygen ( 5 minutes) and air ( 10 minutes). The diode configuration sensor has nearly no response to $\mathrm{H}_{2}$ at this concentration while the layer configuration sensor has a significant response. Comparison of the I-V curves of the two configurations is shown in Figure 3. The layer configuration sensor shows exponential behavior at low voltages and series resistance behavior at higher voltages. An increase in the current for a given voltage is noted upon exposure to $\mathrm{H}_{2}$ for this sensor. However, the diode's $\mathrm{H}_{2}$ sensitivity is less than that noted for the previously investigated $\mathrm{Pd} / \mathrm{SnO}_{2} / \mathrm{SiC}$ sensor with a layer $\mathrm{SnO}_{2}$ configuration [2].

The diode configuration sensor shows complicated behavior as a function of voltage. In air, exponential I-V behavior is noted below $0.4 \mathrm{~V}$. The slope of the exponential changes near $0.4 \mathrm{~V}$ and remains nearly constant from 0.4 to $2.5 \mathrm{~V}$. The sensor does not respond to $\mathrm{H}_{2}$ at this concentration below $1.5 \mathrm{~V}$, while between from 1.5 to 2.5 volts a small response to $\mathrm{H}_{2}$ is noted. Above $2.5 \mathrm{~V}$, series resistance behavior is noted in both the air and $\mathrm{H}_{2}$ mix curves. This sensor does not have the standard Schottky diode characteristics noted in $\mathrm{Pd} / \mathrm{SiC}$ diodes previously investigated [1]. In contrast to the results of reference 2, the layer configuration sensor exhibits more standard Schottky diode behavior. Thus, the diode configuration sensor behavior is obviously different than that of the 
layer configuration sensor. These results suggest that the geometry of the reactive insulator, i.e. whether the $\mathrm{SnO}_{2}$ covers the whole region around the sensor or just underneath the diode, affects the behavior of the sensor. The underlying reason for the effect will be investigated in future studies.

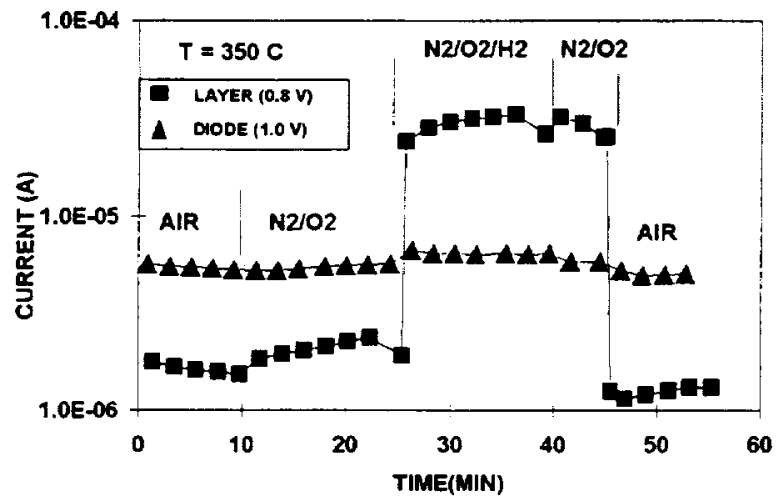

Fig.2. The forward current vs time at $350^{\circ} \mathrm{C}$ upon exposure to $\mathrm{H}_{2}$ mix of the layer configuration sensor and diode configuration sensor.

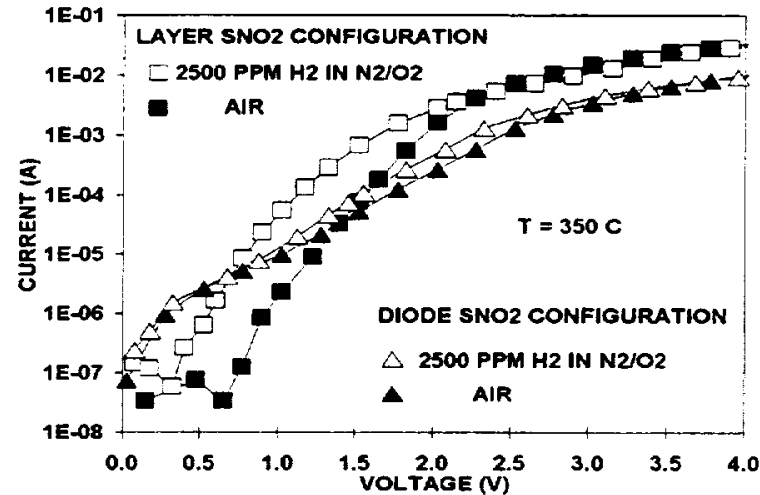

Fig.3. The logarithmic I-V curve at $350{ }^{\circ} \mathrm{C}$ in air and in the $\mathrm{H}_{2}$ mix of the layer configuration sensor and diode configuration sensor.

These results have some similarities to those seen when comparing the $\mathrm{Pd} / \mathrm{SiC}$ sensor to that of the $\mathrm{Pd} / \mathrm{SnO}_{2} / \mathrm{SiC}$ layer configuration sensor in reference 2 . In both cases, increased sensitivity to $\mathrm{H}_{2}$ is noted for sensors in the layer configuration compared to sensors without the layer. In summary, the diode sensitivity and stability is improved when the $\mathrm{SnO}_{2}$ layer covers half the chip compared to that of a sensor where a $\mathrm{SnO}_{2}$ layer does not extend beyond the boundary of the Pd contact.

The difference between the $\mathrm{SnO}_{2}$ layer configuration sensors discussed in this work (diode 1) and in reference 2 (diode 2) is of interest. Both sensors show exponential behavior followed by series resistance behavior at higher voltages (not shown). The low voltage behavior in air of both diodes is shown in Figure 4 in a linear current scale. At lower voltages, diode 2 shows a linear I-V curve (shunt resistive behavior) until at least $0.6 \mathrm{~V}$. The slope of the I-V curve gives an effective resistance of near $2 * 10^{6} \Omega$ which is a value consistent with the resistance of a thin $\mathrm{SnO}_{2}$ film. Above $0.9 \mathrm{~V}$, diode 1 exhibits exponential behavior. In contrast, the $\mathrm{I}-\mathrm{V}$ curve of diode 2 shows noise current below $0.8 \mathrm{~V}$ while above $0.8 \mathrm{~V}$ exponential behavior is observed. Thus, the most significant difference in the behavior of the two diodes is the shunt resistance behavior at lower voltages. These results suggest that differences in the deposition of a $\mathrm{SnO}_{2}$ film can affect the sensor response even if the geometry of the film is the same. Possible differences in the $\mathrm{SnO}_{2}$ film deposition parameters include thickness of the film and stoichiometry of the $\mathrm{SnO}_{2}$.

\subsection{Sensor Packaging}

The ability to package a sensor for a given environment is of fundamental importance to its eventual application. One difficulty with operating sensors which function at higher temperatures than ambient is that a considerable amount of power (order of several watts) may be necessary to properly heat the sensor. For example, temperatures above $300-400{ }^{\circ} \mathrm{C}$ will likely be necessary to optimally measure gases such propylene and methane [1]. The heat power demand to achieve such temperatures may limit sensor use in some applications. Thus, the development of appropriate sensor packaging technology is necessary. Figure 5 shows the schematic of a prototype sensor package 
incorporating a $\mathrm{Pd} / \mathrm{SiC}$ based sensor, temperature detector, and heater. The sensor resides on a micromachined diaphragm structure; this diaphragm structure minimizes the thermal mass and decreases the amount of power necessary to heat the sensor to appropriate temperatures. It also allows heating of the sensor with minimal heating of the adjoining package components. Temperatures up to $600{ }^{\circ} \mathrm{C}$ have been achieved with a heater power of near $1 \mathrm{~W}$. Further, at approximately $500{ }^{\circ} \mathrm{C}$, the packaged $\mathrm{Pd} / \mathrm{SiC}$ sensor with a built-in heater has measured $5000 \mathrm{ppm}$ of $\mathrm{H}_{2}$, ethylene, and methane in $\mathrm{N}_{2}$ (not shown). The methane signal has a longer response time than that of $\mathrm{H}_{2}$ and ethylene, but has the same general shape of I-t curve. This is in contrast to the results at lower temperatures where the methane response was fundamentally different than the sensor response to $\mathrm{H}_{2}$ and propylene [1]. However, as would be expected, degradation of the sensor response occurs with continued high temperature operation. This type of packaging can also be used for a variety of other sensors which would constitute the high temperature electronic nose.

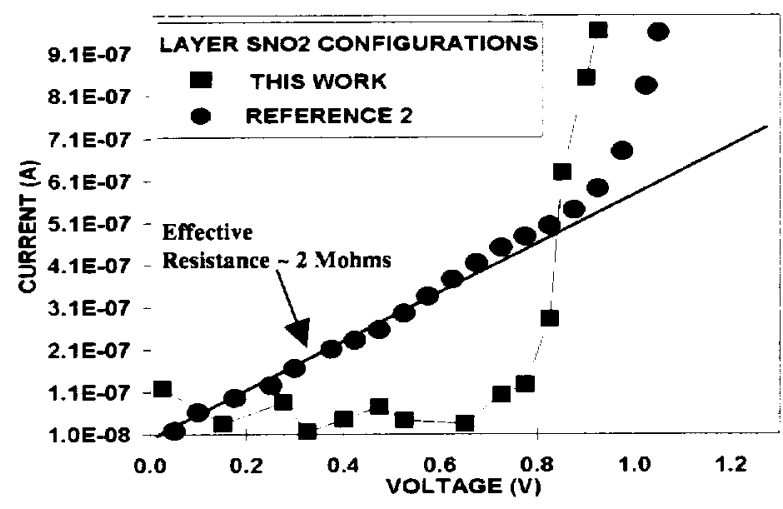

Fig. 4. The I-V curve in air on a linear current scale at $350{ }^{\circ} \mathrm{C}$ of the $\mathrm{Pd} / \mathrm{SnO}_{2} / \mathrm{SiC}$ diode in this work and in reference 2 .

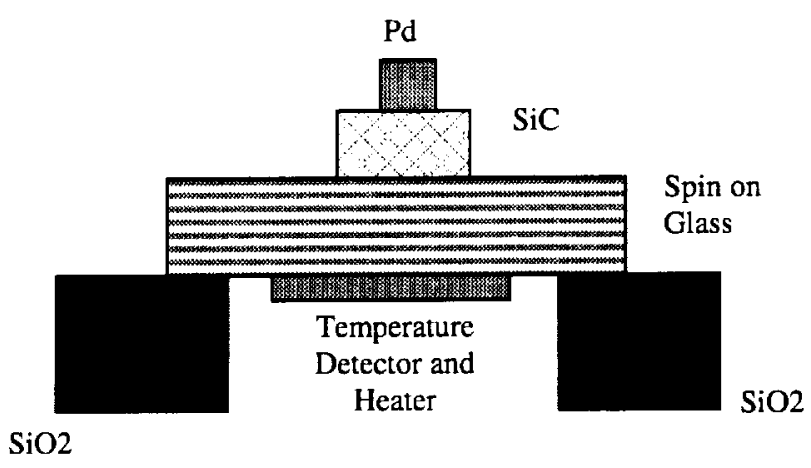

Fig. 5. Schematic drawing of sensor package for SiC-based devices.

\subsection{Conclusions and Future Plans}

The MRIS diode structure shows a dependence on the geometry of the insulator. Further studies with other diode geometries, reactive insulators, and processing conditions are planned. Integration of MRIS and metal alloy-SiC sensors together into an appropriate sensor package is also planned. By integrating SiC-based sensors with various structures into a sensor array, the sensor array can be tailored to meet the detection needs of a range of gas sensing applications.

\subsection{References}

[1] L.-Y Chen, G.W. Hunter, P.G. Neudeck, D. Knight, C.C. Liu, and Q.H. Wu, Proceedings of the Third International Symposium on Ceramic Sensors, H.U. Anderson, M. Liu, and N. Yamazoe, ed., Electrochemical Society Inc., (1996) p. 92, and references therein.

[2] G.W. Hunter, P.G. Neudeck, L.-Y. Chen, D. Knight, C.C. Liu, and Q.H. Wu, Mat. Sci. Forum Vols. 264-268 (1996) pp. 1093.

[3] G.W. Hunter, P.G. Neudeck, L.Y. Chen, C.C. Liu, Q.H. Wu, M.S. Sawayda, Z. Jin, J. Hammond, D. Makel, M. Liu, W.A. Rauch, G. Hall, (1999) NASA TM-1999-209450. 
Public reporting burden for this collection of information is estimated to average 1 hour per response, including the time for reviewing instructions, searching existing data sources, gathering and maintaining the data needed, and completing and reviewing the colection of information. Send comments regarding this burden estimate or any other aspect of this collection of intormation, including suggestions for reducing this burden, to Washington Headquarters Services, Directorate for Information Operations and Reports. 1295 Jefferson Davis Hignway. Suite 1204, Aflington, VA 22202-4302, and to the Office of Management and Budget. Paperwork Reduction Project (0704-018B), Washington, DC 20503.

\begin{tabular}{|l|l|l|}
\hline 1. AGENCY USE ONLY (Leave blank) & 2. AEPORT DATE & 3. REPORT TYPE AND DATES COVERED
\end{tabular}

\begin{tabular}{|l|l|l}
\hline & January 2000 & Technical Memorandum \\
\hline
\end{tabular}

\section{TITLE AND SUBTITLE}

Si-Based Gas Sensor Development

\section{FUNDING NUMBERS}

6. AUTHOR(S)

WU-242-82-62-00

G.W. Hunter, P.G. Neudeck, M. Gray, D. Androjna, L-Y. Chen,

R.W. Hoffman, Jr., C.C. Liu, and Q.H. Wu

7. PERFORMING ORGANIZATION NAME(S) AND ADDRESS(ES)

National Aeronautics and Space Administration

John H. Glenn Research Center at Lewis Field

Cleveland, Ohio 44135-3191

8. PERFORMING ORGANIZATION REPORT NUMBER

E-12009

9. SPONSORING/MONITORING AGENCY NAME(S) AND ADDRESS(ES)

10. SPONSORING/MONITORING AGENCY REPORT NUMBER

National Aeronautics and Space Administration

Washington, DC 20546-0001

NASA TM-2000-209653

\section{SUPPLEMENTARY NOTES}

Prepared for the 1999 International Conference on Silicon Carbide and Related Materials sponsored by North Carolina State University, Raleigh, North Carolina, October 10-15, 1999. G.W. Hunter, P.G. Neudeck and M. Gray, NASA Glenn Research Center; D. Androjna, Cortez III Service Corporation, 21000 Brookpark, Road, Cleveland, Ohio 44135; L-Y. Chen, AYT Corporation, 2001 Aerospace Parkway, Brook Park, Ohio 44142; R.W. Hoffman, Jr., Ohio Aerospace Institute, 22800 Cedar Point Road, Brook Park, Ohio 44142; C.C. Liu and Q.H. Wu, Case Western Reserve University, Electronics Design Center, Cleveland, Ohio 44106. Responsible person, Gary W. Hunter, organization code 5510, (216) 433-6459.

12a. DISTRIBUTIONAVAILABILITY STATEMENT

12b. DISTRIBUTION CODE

Unclassified - Unlimited

Subject Category: 35

Distribution: Nonstandard

This publication is available from the NASA Center for AeroSpace Information, (301) 621-0390.

13. ABSTRACT (Maximum 200 words)

Silicon carbide based Schottky diode gas sensors are being developed for applications such as emission measurements and leak detection. The effects of the geometry of the tin oxide film in a $\mathrm{Pd} / \mathrm{SnO}_{2} / \mathrm{SiC}$ structure will be discussed as well as improvements in packaging SiC-based sensors. It is concluded that there is considerable versatility in the formation of SiC-based Schottky diode gas sensing structures which will potentially allow the fabrication of a SiC-based gas sensor array for a variety of gases and temperatures.

\section{SUBJECT TERMS}

Gas; Hydrocarbon; Emission; Sensor; High temperature; Packaging; Electronic nose; Detection; Silicon carbide

\begin{tabular}{|c|c|}
\hline 17. SECURITY CLASSIFICATION & 18. SECURITY CLASSIFICATION \\
OF REPORT & OF THIS PAGE \\
Unclassified & Unclassified
\end{tabular}

10. SECURITY CLASSIFICATION OF ABSTRACT

Unclassified
15. NUMBER OF PAGES 11

16. PRICE CODE

\section{A03}

\section{LIMITATION OF ABSTRACT}

Standard Form 298 (Rev. 2-89)

Prescribed by ANSI Std. Z39-18 298-102 